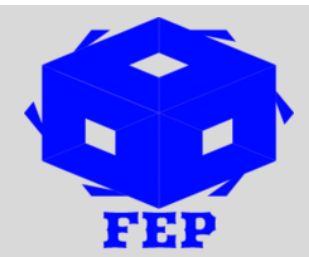

\title{
INVESTIGATION OF SUBSTANCES IN RIVER WATER IN INDIA
}

\author{
Purwah Begum ${ }^{1} \&$ Salman Kabir ${ }^{2}$ \\ ${ }^{1,2}$ Department of Chemistry, Central University of Rajasthan, India
}

*Corresponding Author: Purwah Begum

Article Received: 15-09-19

Accepted: $26-12-19$

Published: $31-01-20$

Licensing Details: Author retains the right of this article. The article is distributed under the terms of the Creative Commons Attribution-Non Commercial 4.0 License (http://www.creativecommons.org/licences/by-nc/4.0/) which permits non-commercial use, reproduction and distribution of the work without further permission provided the original work is attributed as specified on the Journal open access page.

\begin{abstract}
Pollution is increasing in all forms including the water pollution causing damage to the vulnerable aquatic life. In this study, sampling stations were set up to monitor the level of hydrocarbon pollution in the river systems in two selected rivers in India. We used the Dichloromethane for extraction of the sample and analysis were made using the gas chromatography-flame ionization detector. The average value of total petroleum hydrocarbon in the surface water samples is less than or equal to the standard value by DPR of $10 \mathrm{ml} / \mathrm{L}$. The pollution though moderate and low, still pose threat to humans and aquatic organisms and therefore effort should be made by relevant authorities to entails this menace.
\end{abstract}

ABSTRACT

Keywords: Petroleum Hydrocarbons, Pollution, Surface Water, Effluents, Human Activities

\section{INTRODUCTION}

Increased in pollution and associated problems such as global warming has put the very survival of human and other animal and plant species. In most places in the world, the water bodies such as rivers, lakes, wells, are under threat due to the greater level of contamination in the water. The same is the case with the Indian water channel system. The result of increased population and pollution has made most of the Indian water delta system as undrinkable and unfit for domestic, commercial, and agriculture purpose. Thus, it can be said that due to the human intervention, the water which is a basic necessity of life becomes degraded. The wastage from industries in to the water bodies is now a major concern globally. Another issue is that in some places, there is oil exploration and refinement process going on which is also added to the water thus increasing its contamination and degradation (Akporido \& Onianwa, 2015; Daniel \& Nna, 2016). The problem is reported in several International studies that multinational oil companies are polluting the local water bodies (Asia, Jegede, Jegede, Ize-Iyamu, and Akpasubi, 2007). Petroleum is known as most 
powerful source of energy in the $21^{\text {st }}$ century known to men. The petroleum hydrocarbon is an organic pollutant which is causing pollution to water bodies because of accidental spill, disposal, and willful disposal (Adipah, 2019). The main usage of petroleum includes development of raw material, source of heating, manufacturing, and transportation (CCME, 2001). The problem is that crude oil which is often subject to accidental or willful spill in the main water bodies, contains total petroleum hydrocarbons which are highly inflammable. Some portion of the total petroleum vaporize easily while other create a thick drak layer containing dangerous chemicals such as polycyclic aromatic hydrocarbons, xylene, toluene, and benzene. It also possibly contains volatile organic compounds, semi volatile organic compounds, and metals which also possess toxicity (dibofori-Orji, Kalagbor, \& Ekpete, 2019; Alagoa, Godwin, Daworiye, \& Ipeteikumoh, 2018). The outcome of the presence of these toxic contents on water bodies is that it creates serious threat to marine life (Charriau, Bodineau, Ouddane, \& Fischer, 2009). Every year, thousands of tons of these dangerous chemicals enter the water bodies and remain there through the runoff during rain, vehicle emission, automobile waste, oil spills, and municipal and industrial discharges (Inyang, Aliyu, and Oyewale, 2018; Charriau, Bodineau, Ouddane, and Fischer, 2009). It is without any doubt that contamination and pollution of these water bodies affect the survival of aquatic life the result is that it is disturbing the food chain in the water ecosystem (Pocock, Smith, and Baghurst, 1994; Koller, Brown, Spurgeon, and Levy, 2004). In some countries, some of the regulatory authorities are working to put a check on petroleum discharge in the main water bodies (Ritschard, Berg, and Henriquez, 1981; Al-Shwafi, 2008). In this study, the focus is to test the concentration of various petroleum hydrocarbon fraction in the river system in the India.

\section{MATERIALS AND METHODS STUDY AREA}

The focus of the study is river system in India but we used two selected rivers as sampling station. They are located in the Rajasthan province near Jaipur city. The distance between sampled locations was about 2 kilo meters. The main activities around the sampling station include illegal oil bunkering, petty trading, fishing, and farming.

\section{Sample Collection}

We collected water sample for analysis from the selected sampling stations. We used glass bottles of $25 \mathrm{~cm}$ to collect water below the surface. We collected multiple samples from the designated area. Hydrochloric acid is used to preserve the samples collected. These bottles were previously washed and rinsed with dichloromethane. Ice pack vessels is used for transportation to laboratory where these samples were stored at $4^{\circ} \mathrm{C}$ until time for analysis.

\section{Samples Extraction and Determination of Total Petroleum Hydrocarbon}

We filtered water samples and then extracted using the separatory funnel. We put one litre of filtered water in to a separatory funnel with a glass stopper which contains $40 \mathrm{ml}$ of dichloromethane as the solvent of extraction. We shook the separatory funnel for about 7 minutes in order to enable separation of organic layer from the squeous layer. 10 minutes were given to allow equilibrated contents in the separatory funnel to settle out. We repeated 
the process for at least three times for each sample. The phases were separated by filtration leaving the organic layer.

Each of the sample extract was then concentrated with rotary evaporator with water bath at a temperature of $40{ }^{\circ} \mathrm{C}$. Thereafter the concentrated sample extracts were transferred to a bottle previously weighed and then evaporated to dryness (Manahan, 2003; LAWI, 2011).

\section{Sample Clean-Up, Separation and Detection}

We transferred the extracted water samples to a chromatographic column packed with silica gel sherry with about $3 \mathrm{~cm}$ anhydrous sulphate layer on top for removing polar organic substances in the solvent. $25 \mathrm{ml}$ of $\mathrm{n}$-hexane is used for obtaining the hydrocarbon fraction. Using the rotary evaporator at $40 \mathrm{c}$ along with $3 \mathrm{ml}$ eluates concentration for evaporation and then dryness. The extracts were further dissolved in a $4 \mathrm{ml}$ Tetrachloroethylene and an Agilent gas chromatography with flame ionization detector for determining the concentration of total petroleum hydrocarbon in the water sample. Total petroleum hydrocarbon concertation is measured by keeping detector temperature at constant $350 \mathrm{c}$ and the calculating total sum of all aliphatic and aromatic hydrocarbons.

\section{RESULTS AND DISCUSSION}

The table 1 shows the result of the concentrations of total petroleum hydrocarbons. These results describe the individual concentrations of the different fractions of the hydrocarbon constiuents in the surface water of the creek, which sums up the total petroleum hydrocarbons in various stations in different months. For example, in the winter season, the recorded level of concentration of individual hydrocarbon fraction was undetected to $3.24000 \mathrm{ml} / \mathrm{L}$ in station in 3.35 in $\mathrm{C}_{10}$ fraction. The total petroleum hydrocarbon content for the stations are $0.0000 \mathrm{mg} / \mathrm{L}$ station $1,0.055 \mathrm{ml} / \mathrm{L}$, Station 2, $0.0000 \mathrm{ml} / \mathrm{L}$, Station 3 and $3.35 \mathrm{ml} / \mathrm{L}$ Station 4. As the weather got moderate, the repeated results showed that petroleum hydrocarbon content in surface water ranged from not detected to $3.3 .7440 \mathrm{ml} / \mathrm{L}$ in Station 4 in $\mathrm{C}_{20}$ fraction.

Table 1: Total Petroleum Hydrocarbon concentrations in Surface water in December.

\begin{tabular}{|l|l|l|l|l|}
\hline $\begin{array}{c}\text { Carbon } \\
\text { Length } \\
\text { (ml/L) }\end{array}$ & $\begin{array}{c}\text { Workstation } \\
\mathbf{1}\end{array}$ & $\begin{array}{c}\text { Workstation } \\
\mathbf{3}\end{array}$ & $\mathbf{3}$ & $\mathbf{4}$ \\
\hline C7 & - & 0.8533 & - & 0.580853 \\
\hline C8 & - & 0.10085 & - & 0.153888 \\
\hline C10 & - & 0.0555155 & -3.35000 \\
\hline C11 & - & 0.33088 & - & 1.03573 \\
\hline C13 & - & 0.835553 & - & 0.877585 \\
\hline C13 & - & 0.788333 & - & 0.550535 \\
\hline C15 & - & 0.378503 & - & - \\
\hline C16 & - & - & - & - \\
\hline C15 & - & - & - & - \\
\hline C17 & - & - & - & - \\
\hline
\end{tabular}




\begin{tabular}{|l|l|l|l|l|}
\hline C18 & - & - & - & - \\
\hline C19 & - & - & - & - \\
\hline C20 & - & - & - & - \\
\hline C21 & - & - & - & - \\
\hline C23 & - & - & - & - \\
\hline C24 & - & - & - & - \\
\hline C25 & - & - & - & - \\
\hline C26 & - & - & - & - \\
\hline C27 & - & - & - & - \\
\hline C28 & - & - & - & - \\
\hline C29 & - & - & - & - \\
\hline C30 & - & - & - & - \\
\hline C31 & - & - & - & - \\
\hline C32 & - & - & - & - \\
\hline C33 & - & - & - & - \\
\hline C34 & - & - & - & - \\
\hline C35 & - & - & - & - \\
\hline C36 & - & - & - & - \\
\hline C37 & - & - & - & - \\
\hline C38 & - & - & - & - \\
\hline C39 & - & - & - & - \\
\hline C40 & - & - & - & - \\
\hline C41 & - & - & - & - \\
\hline Total & - & 3.3833885 & - & 5.558808 \\
\hline
\end{tabular}

Table 2: Total Petroleum Hydrocarbon concentrations in Surface water in February

\begin{tabular}{|c|c|c|c|c|}
\hline $\begin{array}{l}\text { Carbon } \\
\text { Length } \\
\text { (ml/L) }\end{array}$ & $\begin{array}{c}\text { Workst: } \\
\text { ion } 1\end{array}$ & $\begin{array}{r}\text { Workst } \\
\text { ion } 2\end{array}$ & $\begin{array}{c}\text { Worksta } \\
\text { ion } 3\end{array}$ & $\begin{array}{l}\text { Workstat } \\
\text { ion } 5\end{array}$ \\
\hline C8 & - & - & - & \\
\hline C9 & - & 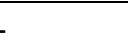 & 5.22523 & 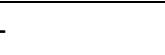 \\
\hline C10 & - & 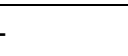 & - & \\
\hline C11 & - & 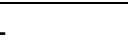 & - & . \\
\hline C12 & - & - & - & \\
\hline C13 & - & 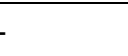 & - & - \\
\hline C14 & - & - & - & \\
\hline C15 & - & - & - & - \\
\hline C16 & - & - & - & \\
\hline C17 & - & - & - & \\
\hline
\end{tabular}




\begin{tabular}{|l|l|l|l|l|}
\hline C18 & - & - & - & - \\
\hline C19 & 5.25355 & - & - & - \\
\hline C20 & - & - & - & 0.09870 \\
\hline C21 & - & - & - & - \\
\hline C22 & - & - & - & 2.03595 \\
\hline C23 & - & - & - & - \\
\hline C24 & - & - & - & 0.36885 \\
\hline C25 & - & - & - & - \\
\hline C26 & 5.5352 & - & - & 2.50623 \\
\hline C27 & - & - & - & - \\
\hline C28 & - & - & - & 0.02883 \\
\hline C29 & - & - & - & - \\
\hline C30 & - & 0.57555 & - & 2.92272 \\
\hline C31 & - & - & - & - \\
\hline C32 & - & 0.05629 & - & - \\
\hline C33 & - & - & - & - \\
\hline C34 & - & 0.67575 & - & - \\
\hline C35 & - & - & - & - \\
\hline C36 & - & 2.89995 & - & - \\
\hline C37 & - & - & - & - \\
\hline C38 & - & - & - & - \\
\hline C39 & - & - & - & - \\
\hline C40 & - & - & - & - \\
\hline Total & 8.58765 & 5.20552 & 5.22523 & 6.85027 \\
\hline
\end{tabular}

Table 3: Total Petroleum Hydrocarbon concentrations in Surface water in April

\begin{tabular}{|l|l|l|l|l|}
\hline $\begin{array}{c}\text { Carbon } \\
\text { Length } \\
(\mathbf{m l} / \mathbf{L})\end{array}$ & $\mathbf{1}$ & $\mathbf{2}$ & $\mathbf{3}$ & $\mathbf{4}$ \\
\hline C8 & - & & - & - \\
\hline C9 & 0.00638362 & - & - & - \\
\hline C10 & 0.0208688 & - & - & - \\
\hline C11 & 0.0238608 & - & - & - \\
\hline C12 & 0.0636660 & - & - & - \\
\hline C13 & 0.0368060 & - & - & - \\
\hline C14 & 0.0226088 & - & - & - \\
\hline C15 & 0.0222258 & - & - & - \\
\hline C16 & 0.00800206 & - & - & - \\
\hline C17 & 0.205536 & - & - & - \\
\hline C18 & 0.0533052 & - & - & 0.2883 \\
\hline
\end{tabular}




\begin{tabular}{|l|l|l|l|l|}
\hline C19 & 0.0255862 & - & 0.38328 & 2.8383 \\
\hline C20 & 0.363688 & 0.22086 & 2.36236 & 3.8660 \\
\hline C21 & - & - & - & - \\
\hline C22 & 0.886822 & 2.25385 & 0.6556 & 0.2238 \\
\hline C23 & - & - & - & - \\
\hline C24 & 0.388562 & 0.30685 & 0.03606 & 2.8685 \\
\hline C25 & - & - & - & - \\
\hline C26 & 0.826883 & 2.58358 & 2.66326 & 0.3868 \\
\hline C27 & - & - & - & - \\
\hline C28 & 2.52888 & 0.88638 & 0.68362 & 2.0286 \\
\hline C29 & - & - & - & - \\
\hline C30 & 2.66226 & 2.20038 & 2.28282 & 0.0286 \\
\hline C31 & - & - & - & - \\
\hline C32 & 0.833862 & 2.80658 & - & - \\
\hline C33 & - & - & - & - \\
\hline C34 & 2.82288 & - & - & - \\
\hline C35 & - & - & - & - \\
\hline C36 & 0.0262823 & - & - & - \\
\hline C37 & - & - & - & - \\
\hline C38 & 0.0026628 & - & - & - \\
\hline C39 & - & - & - & - \\
\hline C40 & 0.000828552 & - & - & -20.2626 \\
\hline Total & 20.23632 & 8.05656 & 6.63388 & \\
\hline
\end{tabular}

Table 4: Total Petroleum Hydrocarbon concentrations in Surface water in June

\begin{tabular}{|l|l|l|l|l|}
\hline $\begin{array}{c}\text { Carbon } \\
\text { Length } \\
(\mathbf{m l} / \mathbf{L})\end{array}$ & $\begin{array}{c}\text { Workstation } \\
\mathbf{1}\end{array}$ & $\begin{array}{c}\text { Workstation } \\
\mathbf{2}\end{array}$ & $\begin{array}{c}\text { Workstation } \\
\mathbf{3}\end{array}$ & $\begin{array}{c}\text { Workstation } \\
\mathbf{4}\end{array}$ \\
\hline $\mathrm{C} 8$ & & - & - & - \\
\hline $\mathrm{C} 9$ & & - & - & - \\
\hline $\mathrm{C} 10$ & - & - & - & - \\
\hline $\mathrm{C} 11$ & & - & - & - \\
\hline $\mathrm{C} 12$ & - & - & - & - \\
\hline $\mathrm{C} 13$ & - & - & - & - \\
\hline $\mathrm{C} 14$ & - & - & - & - \\
\hline $\mathrm{C} 15$ & - & - & - & - \\
\hline $\mathrm{C} 16$ & - & - & - & - \\
\hline $\mathrm{C} 17$ & - & 0.23333 & - & - \\
\hline $\mathrm{C} 18$ & 0.62268 & 1.62613 & - & - \\
\hline
\end{tabular}




\begin{tabular}{|l|l|l|l|l|}
\hline C19 & 0.33316 & 0.31213 & - & 0.83333 \\
\hline C20 & 3.08302 & 2.63032 & - & 0.23366 \\
\hline C21 & - & - & - & - \\
\hline C22 & - & 0.30668 & - & - \\
\hline C23 & - & - & - & - \\
\hline C24 & 0.13663 & 0.66663 & 2.6616 & 1.63236 \\
\hline C25 & - & - & - & - \\
\hline C26 & - & 0.36333 & 3.8666 & 0.66666 \\
\hline C27 & - & - & - & - \\
\hline C28 & - & 0.18333 & 3.6108 & 2.30661 \\
\hline C29 & - & - & - & - \\
\hline C30 & - & 0.68266 & 3.6282 & 2.33360 \\
\hline C31 & - & - & - & - \\
\hline C32 & - & 0.60062 & - & 0.33226 \\
\hline C33 & - & - & - & - \\
\hline C34 & - & 2.36320 & - & - \\
\hline C35 & - & - & - & - \\
\hline C36 & - & - & - & - \\
\hline C37 & - & - & - & - \\
\hline C38 & - & - & - & - \\
\hline C39 & - & - & - & - \\
\hline C40 & - & - & - & - \\
\hline Total & 3.31631 & 1.63623 & 16.0603 & 6.60661 \\
\hline
\end{tabular}

Table 5 and table 6 shows the average concentration of the total petroleum hydrocarbons of the different stations in total. The obtained value is $2.752 \pm 2.597,5.927 \pm 2.905$, $9.772 \pm 2.523$ and $20.009 \pm 7.275 \mathrm{ml} / \mathrm{L}$ respectively for the month of December, February, April, and June respectively. Also, the mean levels of concentrations of total petroleum hydrocarbon in the various stations revealed that $5.937,7.567,7.705$, and 9.072 were were recorded for stations 1,2,3 and 4 respectively. The average concentration level of total petroleum hydrocarbon reported were less than the permitted limit of $10.00 \mathrm{ml} / \mathrm{L}$ in water and less than then European Union Environment Protection Agencies permittable limit of $300 \mu \mathrm{g} / 1$ in river water (DPR, 2011; EUEPA, 2019). If we compare our results with some of the other studies so it shows that our average result was less than the results of some of the other studies. For example, Daniel and Nna (2016) reported range which was above our reported limit. Similarly, the reported limit by Suratmen (2013) was also above our reported limit. Another study conducted in Gulf of Mexico showed higher limit compare to the our reported one (Sammarco, Kolian, Werby, Bouldin, Subra, \& Porter, 2013).

All in all, we did not find the lighter fractions of the total petroleum in most of the stations we setup over the entire period of the study. A possible reason for this can be the hot temperature and strong wind causing rapid evaporation (Hanson, Helveyand, \& Starch, 2003). Another possible explanation can be that crude oil which is extracted along this 
water channel may not contain enough quantity of such fractions. Because in different seasons, the waterfall varies, so it can be one reason for different reported figures. Mostly, the river systems we studied moves in one direction and it also accounts for the low presence of total petroleum hydrocarbon. The reason can be the higher number of grasses and trees which are grown on the bank of a river which absorb some of the hydrocarbon fraction. The annual flooding also causes the reduction in the total content of the hydrocarbon. The resulting flood overflows the water and moves the hydrocarbons at adjoining trees, grass, and land. It can be argued that it is the self-purification mechanism of fresh water in order to reduce the contamination of total petroleum hydrocarbons in the system.

Table 5: Mean Bimonthly Concentrations $(\mathrm{ml} / \mathrm{L})$ of Total Petroleum Hydrocarbons in Surface Water at the different Stations

\begin{tabular}{|l|ll|l|l|}
\hline \multirow{2}{*}{ Stations } & \multicolumn{3}{|c|}{ Months } & \\
\cline { 2 - 5 } & December & February & April & June \\
\hline 1 & & 9.599 & 20.235 & 7.529 \\
\hline 2 & 3.392 & 7.205 & 9.055 & 20.537 \\
\hline 4 & & 7.227 & 5.537 & 25.072 \\
\hline Total & 5.779 & 5.950 & 20.252 & 9.909 \\
\hline Mean & 9.972 & 23.559 & 35.095 & 70.037 \\
\hline
\end{tabular}

Table 6: Mean Spatial (Station) Variation of Total Petroleum Concentrations (ml/L) in Surface Water within the examined Months

\begin{tabular}{|l|l|l|l|l|}
\hline Stations & Months & \multicolumn{3}{l|}{} \\
\cline { 2 - 5 } & $\mathbf{1}$ & $\mathbf{2}$ & $\mathbf{3}$ & $\mathbf{4}$ \\
\hline December & - & 3.392 & - & 7.669 \\
\hline February & 9.599 & 6.205 & 6.226 & 7.950 \\
\hline April & 20.237 & 9.055 & 7.736 & 20.272 \\
\hline June & 6.529 & 20.737 & 27.072 & 9.909 \\
\hline Total & 23.362 & 27.290 & 27.929 & 32.279 \\
\hline Mean & $5.937 \pm 3.9707 .567 \pm 2.9567 .705$ & $\pm 9.072 \pm 2.503$ \\
\hline & & & $\underline{5.903}$ & \\
\hline
\end{tabular}

\section{CONCLUSION}

The objective of the study was to measure the total petroleum hydrocarbon in the surface water of the river systems in selected places in India. We compared the contamination level with that of pre-scribed limit set by various agencies. The findings show that there is some proportion of the contamination in the selected water, however, the contamination level is less than the prescribed limit. 


\section{References}

Adipah, S. (2019). Introduction of petroleum hydrocarbons contaminants and its human effects. Journal of Environmental Science and public Health, 3(1), 1-9.

Agbozu, I. E., Ekweozor, I. K. E. and Opuene, K. (2007). Survey of heavy metals in the catfish Synodontisclarias. International Journal of Environmental Science and Technology, 4(1), 93-97.

Agency for Toxic Substances and Disease Registry (ATSDR) (1999). Toxicological profile for total petroleum hydrocarbon. Atlanta, G. A. US Department of Health and Human Services, Public Health Services.

Akporido, S. O. and Onianwa, P. C. (2015). Heavy metals and total petroleum hydrocarbon concentration in surface water of Esi River, Western Niger Delta. Research Journal of Environmental Sciences, 9(2), 88100.

Alagoa, K. J., Godwin, J., Daworiye, P. S. and Ipeteikumoh, B. (2018). Evaluation of total hydrocarbon (TPH) in sediments and aquatic macrophytes in the River Nun, Amasoma Axises, Niger Delta, Nigeria. International Journal of Environmental and Agriculture Research, 4(2), 63-67.

Al-Shwafi, N. A. A. (2008). Total petroleum hydrocarbon carcinogens in commercial fish in the Red Sea and Gulf of Aden-Yemen. Marine Science, 9, 15-28.

Asia, I. O., Jegede, D. A., Jegede, D. A., Ize-Iyamu, O.K. and Akpasubi, E. B. (2007). The effects of petroleum exploration and production operations on the heavy metals contents of soil and groundwater in the Niger Delta. Journal of Physical Sciences, 2, 271-275.

CCME (2001). Backgrounder - petroleum hydrocarbons in soil.

Charriau, A., Bodineau, L., Ouddane, B. and Fischer, C. J. (2009). Polycyclic aromatic hydrocarbons and n-alkanes in sediments of the upper Scheldt River Basin: Contamination levels and source apportionment. Journal of Environmental Monitoring, 11(5), 106-109.

Daniel, I. E. and Nna, P. J. (2016). Total petroleum hydrocarbon concentration in surface water of Cross River estuary, Niger Delta Nigeria. Asian Journal of Environment and Ecology, 1(2), 1-7.

Department of petroleum Resources (DPR), (2011). Environmental Guidelines and Standards for the Petroleum Industries in Nigeria (EGASPIN). Revised edition, Universal Press, Lagos, Nigeria. 276-297.

Dibofori-Orji, A. N., Kalagbor, I. and Ekpete, O. A. (2019). The total petroleum hydrocarbon contents of the ambient air within Port Harcourt and environs. Chemistry Research Journal, 4(3), 117-123.

European Union of Environmental Protection Agency (EUEPA), (2009). Framework for the use of Rapid Measurement Techniques (RMT) in the risk management of sediment and water contamination. UK. 
Ezekwe, C. I., and Edoghotu, M. I. (2015). Water quality and environmental health indicators in the Andoni River estuary, Eastern Niger Delta of Nigeria. Environmental Earth Sciences, 74(70), 6123-6136.

Gustafson, J. B. (2007). Using TPH in risk-based corrective active.

Hanson, J., Helveyand, M. and starch, R. (2003). Non-fishing impacts to essential fish habitat and recommended conservation measures. Long Beach (CA): National Marine Fisheries Service (NOAA Fisheries) Southwest Region. 1-75.

Inyang, S. E., Aliyu, A. B. and Oyewale, A. o. (2018). Total petroleum content in surface water and sediment of Qua-Iboe River, Ibeno, Akwa_Ibom State, Nigeria. Journal of Applied Science and Environmental Management, 22(12), 1953-1959.

Ite, A. E., Harry, T. A., Obadimu, C. O., Asuaiko, E. R. and Inimi, I.J. (2018). Petroleum hydrocarbons contamination of surface and ground in the Niger Delta Region of Nigeria. Journal of Environment Pollution and Human Health, 6(2), 51-61.

Kachel, J. M. (2008). Particularly sensitive sea areas: The IMO's role in protecting vulnerable marine areas. Springer, New York (NY) USA.

Koller, K., Brown, T., Spurgeon, A. and Levy, L. (2004). Recent development in low level exposure and intellectual impairment in children. Environmental Health Perspective, 112(9), 987-994.

Laboratory Analytical Work Instruction (LAWI), (2011). For the determination of total petroleum hydrocarbon in soil/sediment/sludge in gas chromatography. Published by Fugro, (Nigeria) Limited. 3: 9.

Maioli, O. L., Rodrigues, C. K., Knoppers, B. A. and Azevedo, D. (2011). Distribution and sources of aliphatic and polycyclic aromatic hydrocarbons in suspended particulate matter in water from two Brazilian estuarine systems. Continental Shelf Research, 31(10), 1116-1127.

Manahan, S. E. (2003). Water pollution in Environmental Chemistry (4 ${ }^{\text {th }}$ edn.). Brooks/Cole Publishing Company, Caleidonai, 146-182.

Marine Department of Environmental Protection, Land and Water Quality Division (MDEP), (2004). Integrated water quality monitoring and assessment.

Nduka, J. K. and Orisakwe, O. E. (2010). Water Quality Issues in the Niger Delta Region of Nigeria. Polyaromatic and straight chain hydrocarbons in some selected surface waters. Water Quality, Exposure and Health, 2(2), 65-74.

Pocock, S. J., Smith, M., \& Baghurst, P. (1994). Environmental lead and children's intelligence; A systematic renew of epidemiological evidence. British Medical Journal, 304, 1189-1197.

Ritschard, R., Berg, V., \& Henriquez, M. (1981). Estuary impacts of fossil fuel-based energy technology. A study, Energy and Environment Division, University California, Berkeley, CA, Rep. LBL-13145: 1-62.

Sammarco, P. W., Kolian, R. S., Werby, A. R., Bouldin, I. J., Subra, W. A. and Porter, S. A. (2013). Distribution and concentrations of petroleum hydrocarbons associated with the BP/Deep water Horizon Oil Spill, Gulf of 108 Mexico. Marine Pollution Bulletin, 73, 129-143. 
Suratman, S. (2013). Distribution of total petrogenic hydrocarbon in Dungun River basin, Malaysia. Oriental Journal of Chemistry, 29(1), 77-80.

Tongo, I., Ezemonye, L. and Akpeh, K. (2017). Distribution, characterization and human health risk assessment of polycyclic aromatic hydrocarbons (PAHs) in Ovia River, Southern Nigeria. Environmental Monitoring and Assessment, 189(6), 247.

United States Environmental Protection Agency (USEPA), (2007). Non-halogenated organics using GC/FID. USEPA, Washinton, DC.

Wokoma, O. A. F. (2014). Levels of total hydrocarbons in water and sediment of a polluted tidal creek, Bonny River, Niger Delta, Nigeria. Journal of Scientific and Technology Research, 3(12), 351-354. 